Supporting Information

\title{
Dual-channel imaging of amyloid- $\beta$ plaques and peroxynitrite to illuminate their correlations in Alzheimer's disease using a unimolecular two-photon fluorescent probe
}

Xilei Xie, ${ }^{\dagger}$ Guangzhao Liu, ${ }^{\dagger}$ Yaxin Niu, Chenghui Xu, Yong Li, Jian Zhang, Xiaoyun Jiao, Xu Wang,* and Bo Tang*

College of Chemistry, Chemical Engineering and Materials Science, Key Laboratory of Molecular and Nano Probes, Ministry of Education, Collaborative Innovation Center of Functionalized Probes for Chemical Imaging in Universities of Shandong, Shandong Normal University, Jinan 250014, People's Republic of China

E-mail: tangb@sdnu.edu.cn; wangxu@sdnu.edu.cn.

${ }^{\dagger}$ These authors contributed equally to this work. 


\section{Contents}

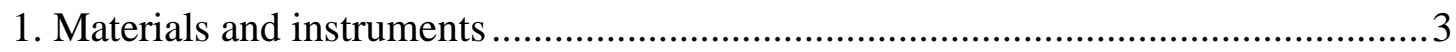

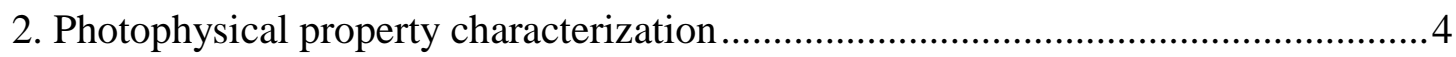

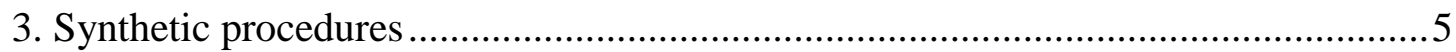

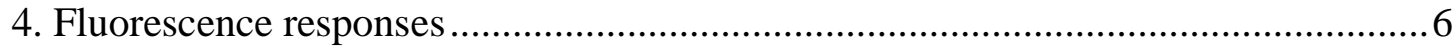

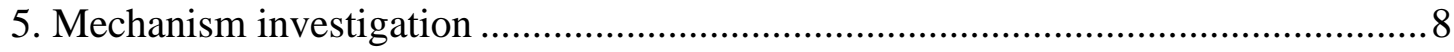

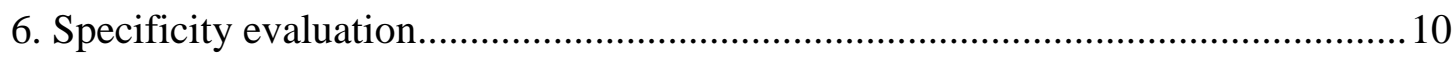

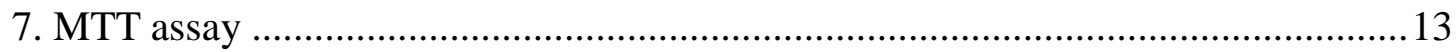

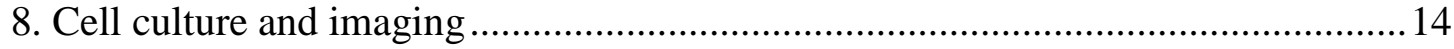

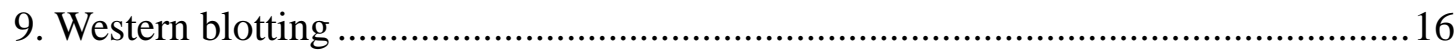

10. Characterization of the nitrated $A \beta$ peptides.................................................... 17

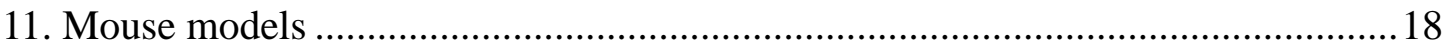

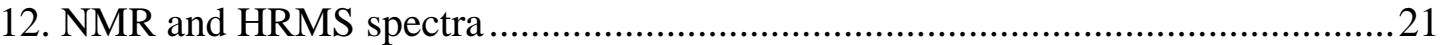




\section{Materials and instruments}

Phosphate buffer solutions were prepared using distilled water. 6-Amino-2-naphthoic acid, 2-aminobenzenethiol, Congo red, GSH, Cys, and Hcy were purchased from Aladdin Chemistry. Human $A \beta_{42}$ peptide was obtained from Macklin. 3-Morpholinosydnonimine hydrochloride (SIN-1) was acquired from Sigma-Aldrich. RAGE antibody, goat anti-rabbit $\operatorname{IgG}(\mathrm{H}+\mathrm{L})$ and FPS-ZM1 were purchased from ThermoFisher Scientific. DMEM medium, fetal bovine serum, penicillin, and streptomycin were obtained from Gibco Invitrogen. Other chemical reagents were acquired from commercial sources and directly used without further purification.

Peroxynitrite $\left(\mathrm{ONOO}^{-}\right)$solution was prepared as previous method. Briefly, a mixture of sodium nitrite $(0.6 \mathrm{M})$ and hydrogen peroxide $(0.7 \mathrm{M})$ was acidified with hydrochloric acid $(0.6 \mathrm{M})$, and sodium hydroxide $(1.5 \mathrm{M})$ was added within $1-2 \mathrm{~s}$ to make the solution alkaline. The $\mathrm{ONOO}^{-}$concentration was estimated by using an extinction coefficient of $1670 \mathrm{M}^{-1} \mathrm{~cm}^{-1}$ at $302 \mathrm{~nm} \cdot \mathrm{C}_{\mathrm{ONOO}}{ }^{-}=\mathrm{Abs}_{302 \mathrm{~nm}} / 1.67(\mathrm{mM})$. Hydrogen peroxide $\left(\mathrm{H}_{2} \mathrm{O}_{2}\right)$, hypochlorite $\left(\mathrm{ClO}^{-}\right)$, and tert-butyl hydroperoxide $(t-\mathrm{BuOOH})$ were delivered from commercial aqueous solutions respectively. Nitric oxide (NO) was used from a stock solution prepared by sodium nitroprusside. Singlet oxygen $\left({ }^{1} \mathrm{O}_{2}\right)$ was generated in situ by addition of the $\mathrm{H}_{2} \mathrm{O}_{2}$ stock solution into a solution containing 10 equiv. of $\mathrm{HClO}$. Superoxide solution $\left(\mathrm{O}_{2}{ }^{--}\right)$was prepared by adding $\mathrm{KO}_{2}$ to dry dimethylsulfoxide and stirring vigorously for $10 \mathrm{~min}$. Hydroxyl radicals $\left({ }^{\circ} \mathrm{OH}\right)$ was generated in situ by reaction of $\mathrm{Fe}^{2+}$ with $\mathrm{H}_{2} \mathrm{O}_{2}$.

$\mathrm{A} \beta$ aggregates were prepared using the commercial human $\mathrm{A} \beta_{42}$ peptide as previous method. Monomeric $\mathrm{A} \beta_{42}$ was first dissolved in 1, 1, 1, 3, 3, 3-hexafluoro-2-propanol (HFIP) and sonicated with ice for $10 \mathrm{~min}$. Subsequently, the samples were divided into aliquots, and the HFIP was evaporated and stored at $-20{ }^{\circ} \mathrm{C}$ until used. The $\mathrm{A} \beta_{42}$ was then redissolved in DMSO, incubated with shaking at $37{ }^{\circ} \mathrm{C}$ for $24 \mathrm{~h}$. The final concentration of $\mathrm{A} \beta_{42}$ was $0.5 \mathrm{mM}$. 
NMR spectroscopic characterization was taken on a Bruker Advance $400 \mathrm{MHz}$ spectrometer. HRMS spectra were obtained by a Bruker MaXis UHR-TOF instrument. Absorption spectra were recorded on a UV-1700 spectrophotometer, and fluorescence measurements were done using a FLS-980 fluorospectrometer from Edinburgh Instruments. The response mechanism of probe was monitored by HPLC-MS on an Ultimate 3000 LC system coupled with an LCQ Fleet mass spectrometer. Western blotting was imaged using a ChemiDoc ${ }^{\mathrm{TM}}$ Touch Imaging System. Two-photon fluorescence imaging of live cells and tissues was performed on a Zeiss LSM 880 confocal laser scanning microscope.

\section{Photophysical property characterization}

The probe was dissolved in DMSO to produce $5 \mathrm{mM}$ stock solution, which was diluted to $20 \mu \mathrm{M}$ as the testing solutions with phosphate buffer (50 mM, pH 7.4). To test the UV-vis absorption spectra of the probe in the presence of $A \beta$ aggregates or $\mathrm{ONOO}^{-}$, aliquots of probe stock solutions were diluted with phosphate buffer $(50 \mathrm{mM}$, $\mathrm{pH}$ 7.4) and treated with $\mathrm{A} \beta$ aggregates or $\mathrm{ONOO}^{-}$to make sure both probes and analytes were kept at the desired final concentrations. The testing solutions were quickly and vigorously shaken. The absorption spectra were recorded after incubation at $37^{\circ} \mathrm{C}$ for $5 \mathrm{~min}$.

The probe was dissolved in DMSO to produce $500 \mu \mathrm{M}$ stock solution, which was diluted to $2 \mu \mathrm{M}$ as the testing solutions with phosphate buffer (50 mM, pH 7.4). To test the fluorescence responses of the probe towards $\mathrm{A} \beta$ aggregates, $\mathrm{ONOO}^{-}$or other analytes, aliquots of probe stock solutions were diluted with phosphate buffer $(50 \mathrm{mM}$, $\mathrm{pH}$ 7.4) and treated with analytes to make sure both probes and analytes were kept at the desired final concentrations. The testing solutions were quickly and vigorously shaken. The fluorescence spectra were recorded after incubation at $37^{\circ} \mathrm{C}$ for $5 \mathrm{~min}$. The blue emission and green emission were acquired with excitation at $340 \mathrm{~nm}$ and $380 \mathrm{~nm}$, respectively. To test the time course of fluorescence response of the probe towards $\mathrm{ONOO}^{-}$, the probe stock solution was diluted with phosphate buffer $(50 \mathrm{mM}$, 
$\mathrm{pH}$ 7.4) and treated with $\mathrm{ONOO}^{-}$to make sure both the probe and $\mathrm{ONOO}^{-}$were kept at the desired final concentrations. The fluorescence intensity at $506 \mathrm{~nm}$ was recorded immediately at $37^{\circ} \mathrm{C}$ with excitation at $380 \mathrm{~nm}$.

To investigate whether the probe could simultaneously monitor the coexisting $A \beta$ aggregates and $\mathrm{ONOO}^{-}$, the probe was diluted to $4 \mu \mathrm{M}$ as the testing solutions with phosphate buffer (50 mM, pH 7.4), and the fluorescence intensities at $418 \mathrm{~nm}$ and 506 $\mathrm{nm}$ were recorded with the excitation at $340 \mathrm{~nm}$ and $380 \mathrm{~nm}$, respectively. The probe was first treated with $20 \mu \mathrm{M} \mathrm{A} \beta$ aggregates at $37{ }^{\circ} \mathrm{C}$ for $5 \mathrm{~min}$, and then treated with $20 \mu \mathrm{M} \mathrm{ONOO}^{-}$at $37^{\circ} \mathrm{C}$ for $5 \mathrm{~min}$, and the fluorescence intensities at $418 \mathrm{~nm}$ and 506 $\mathrm{nm}$ were recorded after each treatment, respectively. On the other hand, the probe was first treated with $20 \mu \mathrm{M} \mathrm{ONOO}^{-}$at $37^{\circ} \mathrm{C}$ for $5 \mathrm{~min}$, and then treated with $20 \mu \mathrm{M} \mathrm{A} \beta$ aggregates at $37^{\circ} \mathrm{C}$ for $5 \mathrm{~min}$, and the fluorescence intensities at $418 \mathrm{~nm}$ and $506 \mathrm{~nm}$ were recorded after each treatment, respectively.

\section{Synthetic procedures}

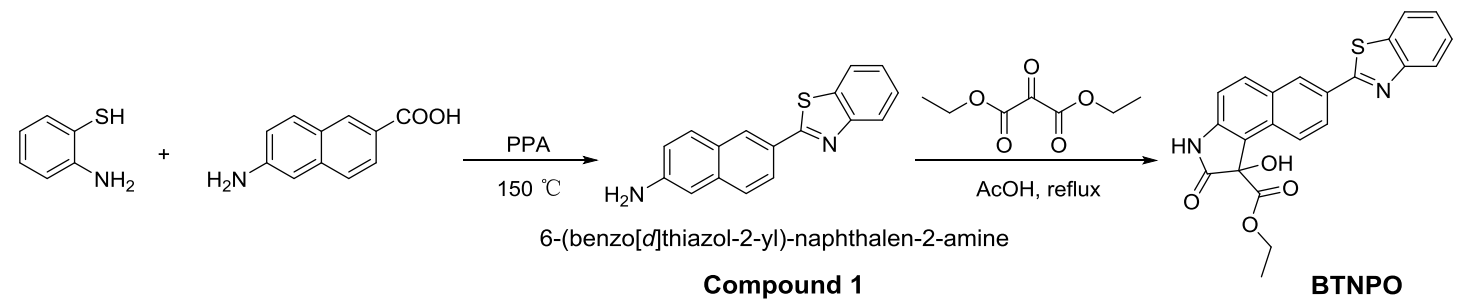

Scheme S1. Synthetic pathway of BTNPO

BTNPO was readily synthesized through a two-step procedure outlined in Scheme S1. 6-(Benzo[d]thiazol-2-yl)-naphthalen-2-amine (Compound 1) was synthesized according to the modified reported procedures. Other chemical reagents were acquired from commercial sources and directly used without further purification. The solvents were distilled or purified before use if necessary.

Synthesis of Compound 1. 6-Amino-2-naphthoic acid (375 mg, $3 \mathrm{mmol}$ ) and 2-aminobenzenethiol (374 mg, $2 \mathrm{mmol}$ ) were added to polyphosphoric acid (PPA, 5 $\mathrm{mL}$ ), and the resulting mixture was stirred at $150{ }^{\circ} \mathrm{C}$ for $15 \mathrm{~h}$. The solution obtained 
after completion of the reaction was added to water $(100 \mathrm{~mL})$, the precipitate was obtained by filtration and was purified by column chromatography on silica gel using dichloromethane, petroleum ether, and triethylamine $(1 / 1 / 0.2, \mathrm{~V} / \mathrm{V} / \mathrm{V})$ as eluent to obtain a solid (320 mg, $58 \%$ ). ${ }^{1} \mathrm{H}$ NMR (400 MHz, DMSO- $\left.d_{6}\right): \delta 8.39$ (s, 1H), 8.12 $(\mathrm{d}, J=7.4 \mathrm{~Hz}, 1 \mathrm{H}), 8.03(\mathrm{~d}, J=7.8 \mathrm{~Hz}, 1 \mathrm{H}), 7.98(\mathrm{dd}, J=8.6,1.9 \mathrm{~Hz}, 1 \mathrm{H}), 7.82(\mathrm{~d}, J$ $=8.8 \mathrm{~Hz}, 1 \mathrm{H}), 7.64(\mathrm{~d}, J=8.7 \mathrm{~Hz}, 1 \mathrm{H}), 7.53(\mathrm{t}, J=7.1 \mathrm{~Hz}, 1 \mathrm{H}), 7.43(\mathrm{t}, J=7.0 \mathrm{~Hz}$, $1 \mathrm{H}), 7.03(\mathrm{dd}, J=8.8,2.2 \mathrm{~Hz}, 1 \mathrm{H}), 6.87(\mathrm{~d}, J=1.9 \mathrm{~Hz}, 1 \mathrm{H}), 5.81(\mathrm{~s}, 2 \mathrm{H}) \mathrm{ppm} .{ }^{13} \mathrm{C}$ NMR (100 MHz, DMSO- $\left.d_{6}\right): \delta 168.03,153.79,148.81,136.70,134.17,130.02$, $127.46,126.47,125.88,125.58,125.23,124.98,124.03,122.35,122.14,119.24$, 105.45 ppm. HRMS (ESI): calculated for $\mathrm{C}_{17} \mathrm{H}_{13} \mathrm{~N}_{2} \mathrm{~S}(\mathrm{M}+\mathrm{H})^{+}$277.0793, found 277.0733 .

\section{Fluorescence responses}

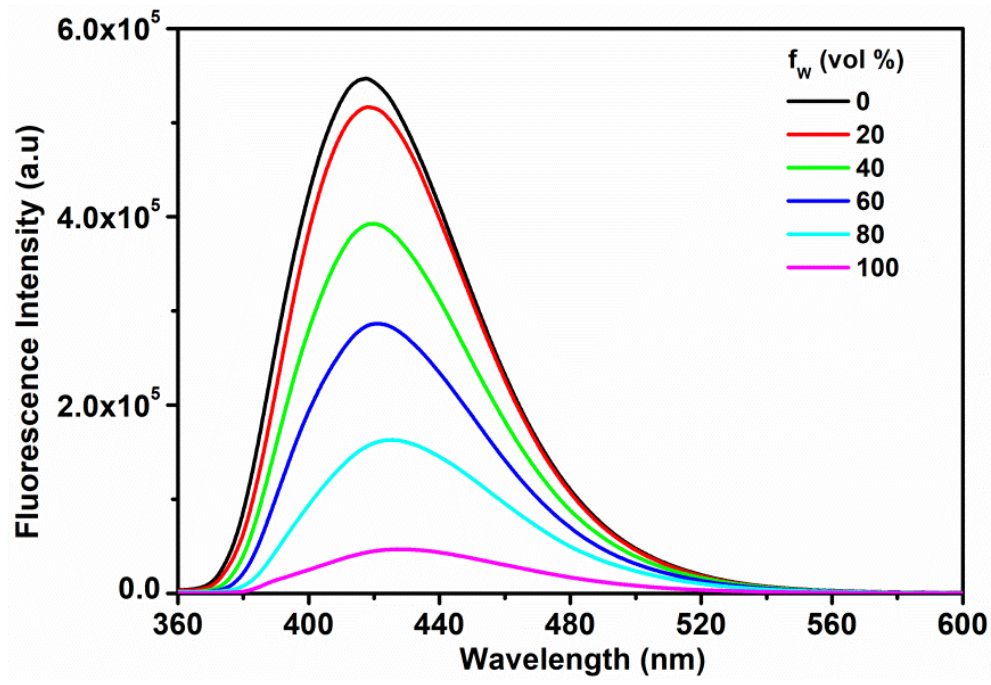

Figure S1. Fluorescence spectra of $2 \mu \mathrm{M}$ BTNPO in ethanol/water mixtures with different water fraction $\left(f_{\mathrm{W}}\right)$. The data were acquired with excitation at $340 \mathrm{~nm}$ at $37^{\circ} \mathrm{C}$. 


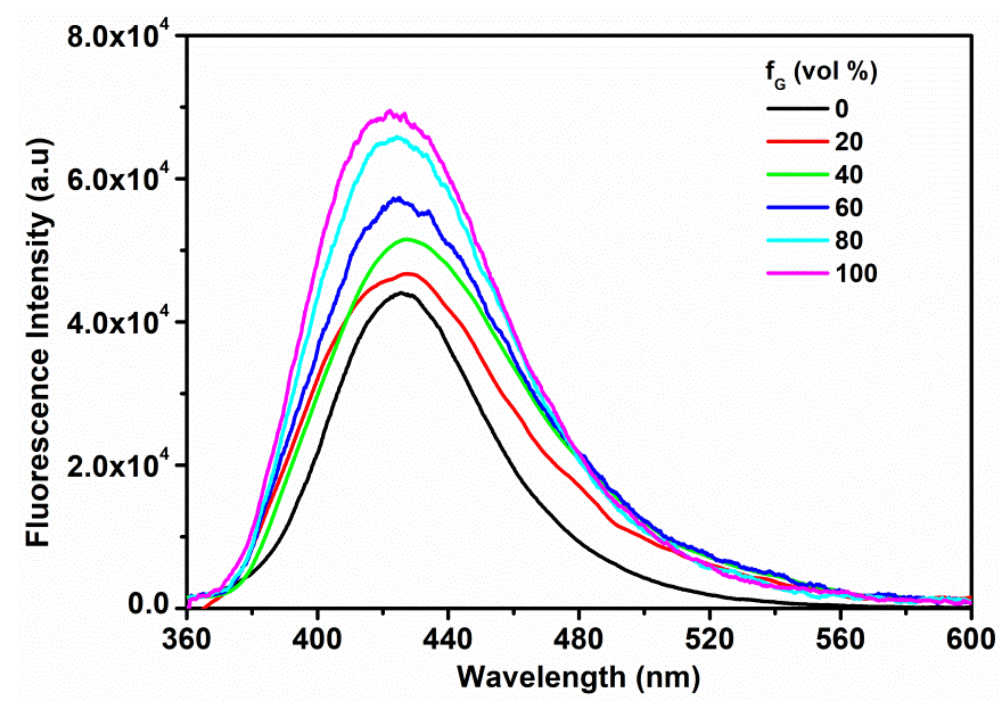

Figure S2. Fluorescence spectra of $2 \mu \mathrm{M}$ BTNPO in glycerol/water mixtures with different glycerol fraction $\left(f_{\mathrm{G}}\right)$. The data were acquired with excitation at $340 \mathrm{~nm}$ at $37{ }^{\circ} \mathrm{C}$. 


\section{Mechanism investigation}

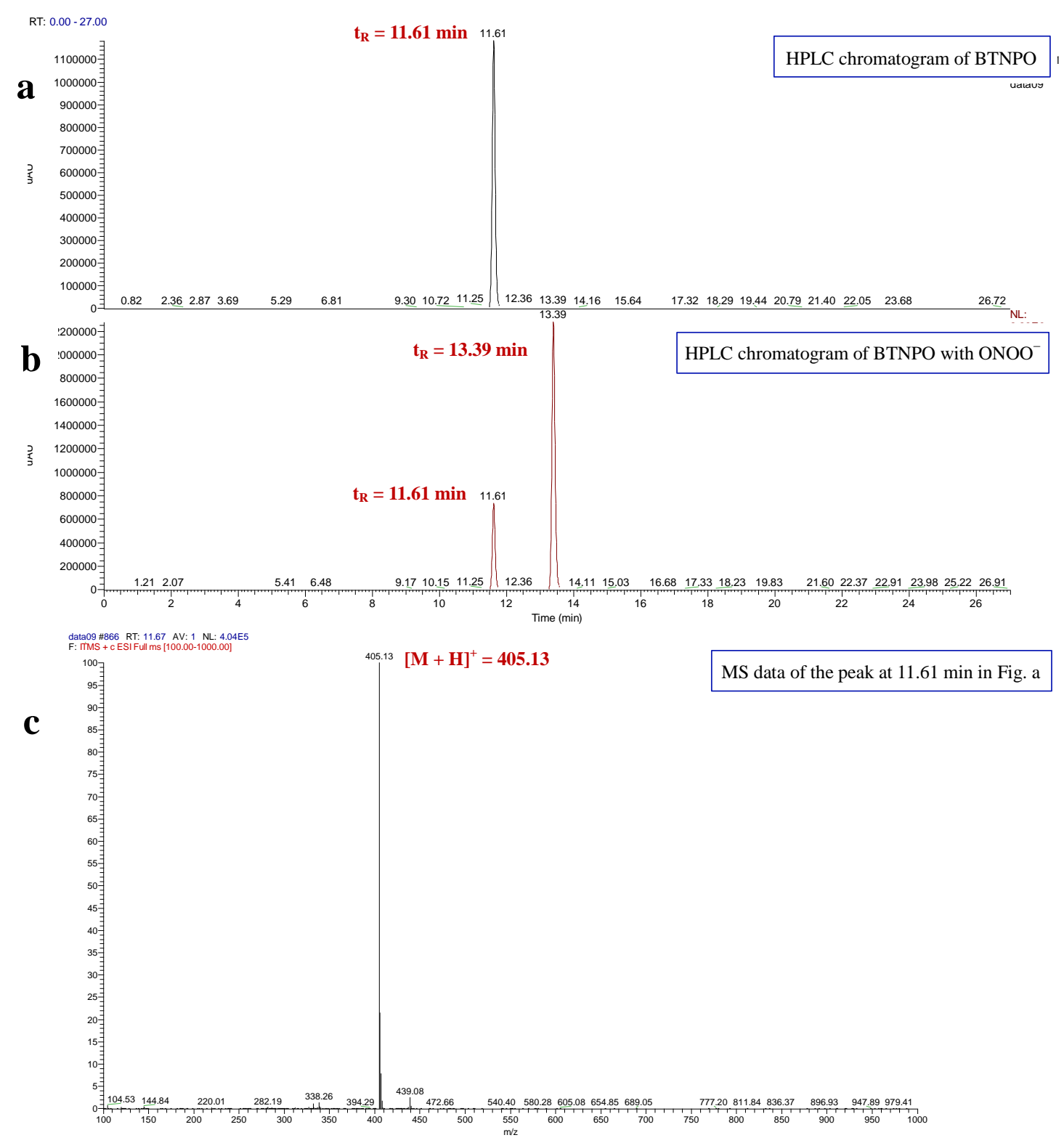



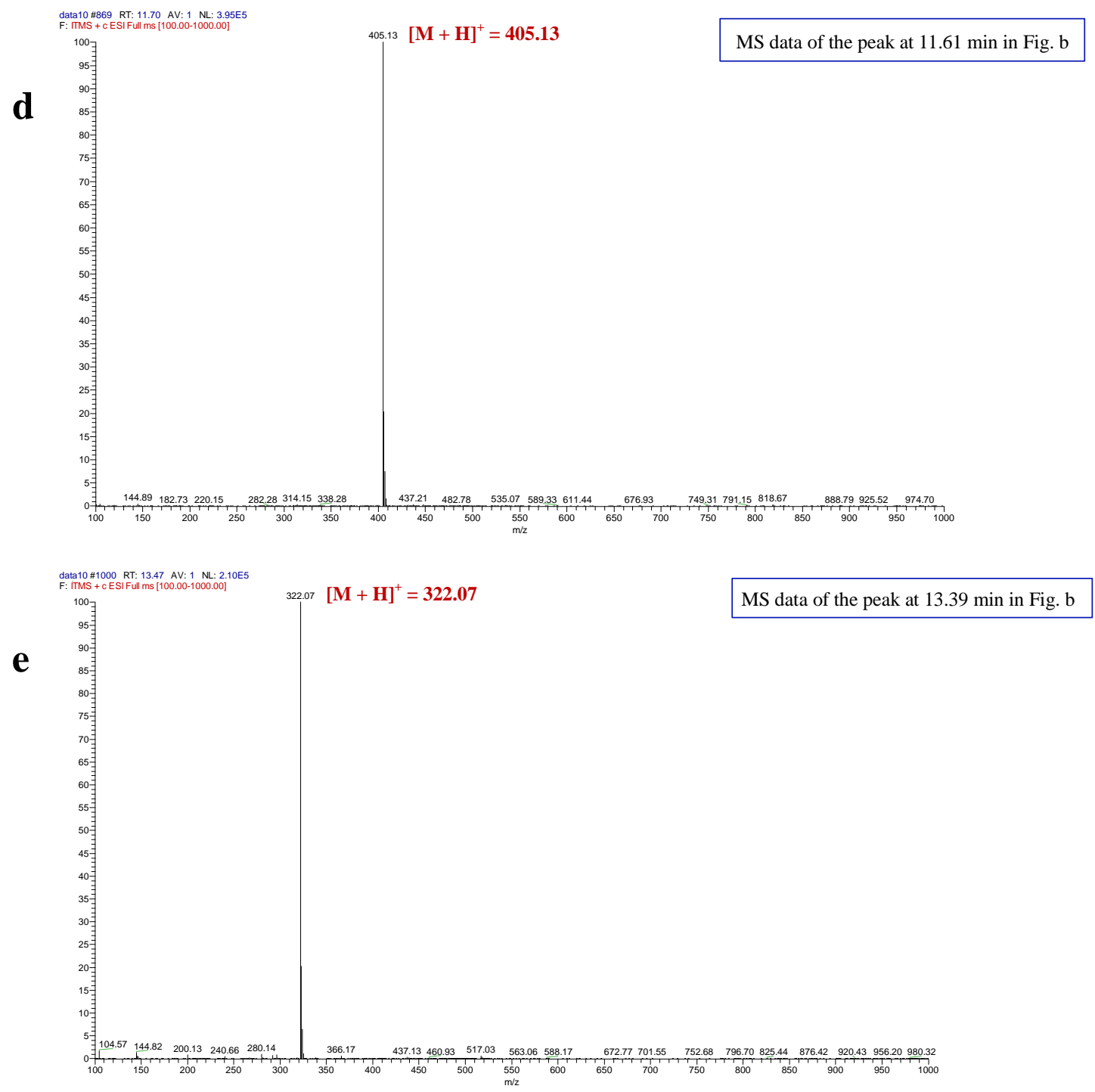

Figure S3. HPLC-MS analysis of the reaction product of BTNPO with $\mathrm{ONOO}^{-}$. BTNPO was incubated with 10 equiv. of $\mathrm{ONOO}^{-}$at $37^{\circ} \mathrm{C}$, and then characterized by HPLC-MS spectrometry. (a) HPLC chromatogram of BTNPO alone. (b) HPLC chromatogram of BTNPO incubated with 10 equiv. of $\mathrm{ONOO}^{-}$. (c) The corresponding MS data of the chromatographic peak at 11.61 min in Figure S1a. (d) The corresponding MS data of the chromatographic peak at 11.61 min in Figure S1b. (e) The corresponding MS data of the chromatographic peak at 13.39 min in Figure S1b. 


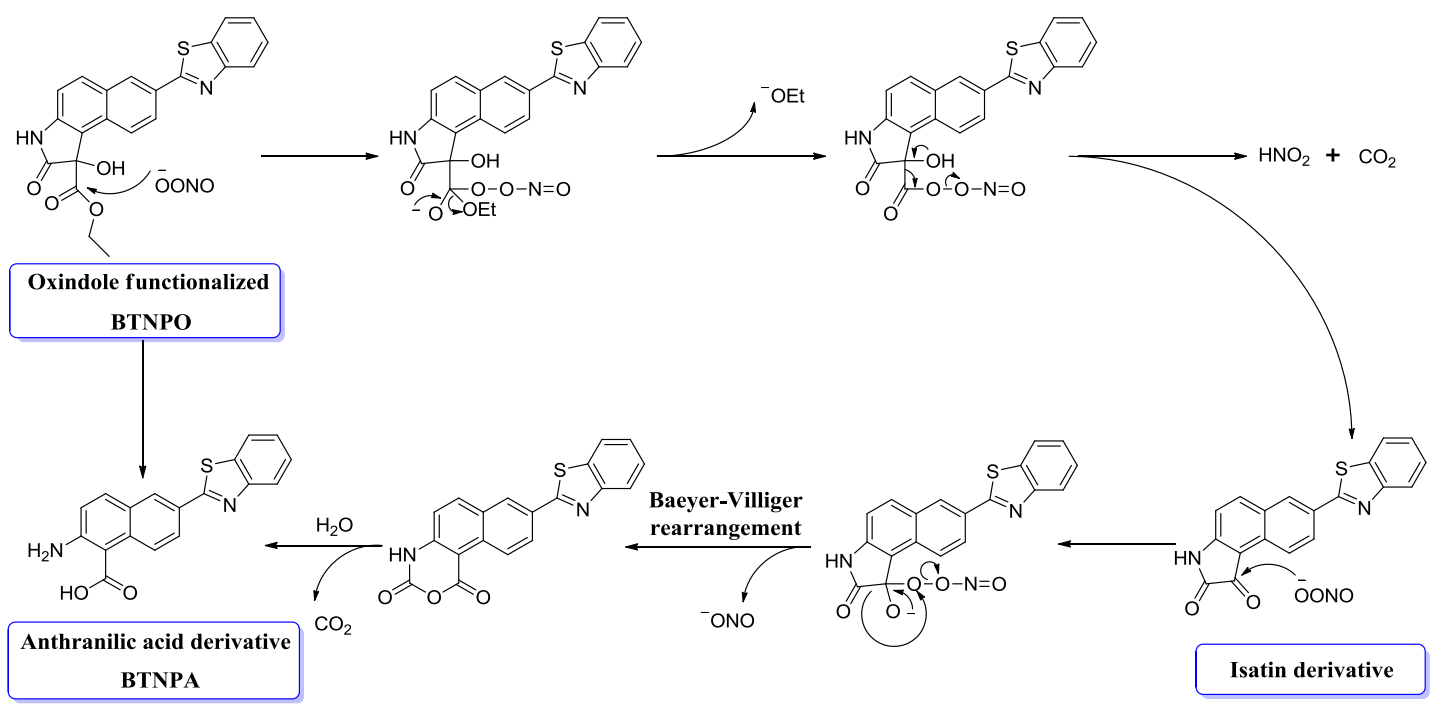

Scheme S2. Proposed reaction pathway of $\mathrm{ONOO}^{-}$and oxindole functionalized probe BTNPO.

\section{Specificity evaluation}
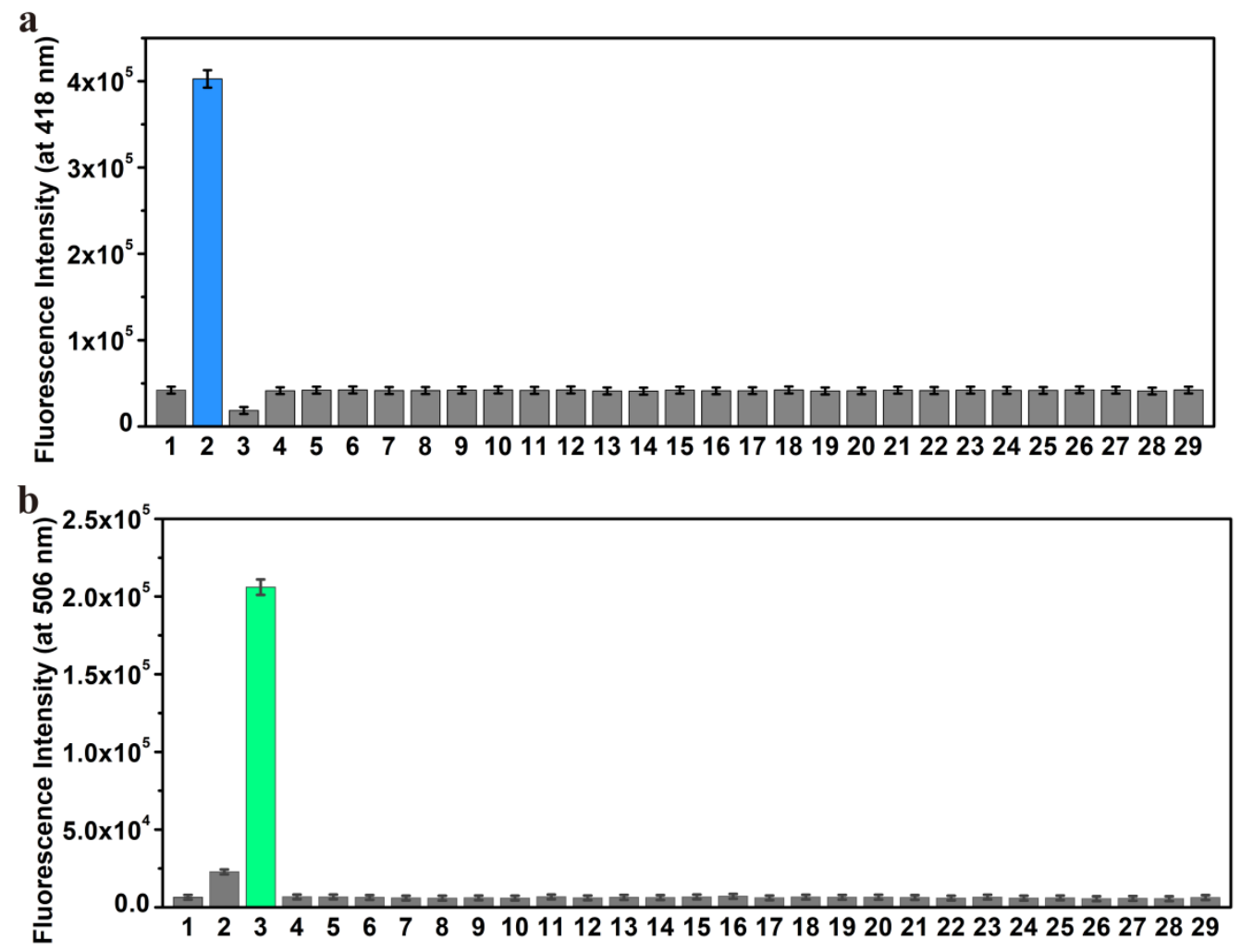

Figure S4. Fluorescence responses of $2 \mu \mathrm{M}$ BTNPO toward $100 \mu \mathrm{M}$ analytes unless otherwise noted: (1) blank, (2) $20 \mu \mathrm{M} \mathrm{A} \beta$ aggregates, (3) $20 \mu \mathrm{M} \mathrm{ONOO}^{-}$, (4) $\mathrm{H}_{2} \mathrm{O}_{2}$, (5) $\mathrm{ClO}^{-}$, (6) $\mathrm{O}_{2}{ }^{\cdot-}$, (7) ${ }^{\circ} \mathrm{OH},(8){ }^{1} \mathrm{O}_{2}$, (9) $t$-BuOOH, (10) $\mathrm{NO},(11) \mathrm{NO}_{2}^{-}$, (12) $5 \mathrm{mM}$ 
GSH, (13) 5 mM Cys, (14) Hcy, (15) $\mathrm{H}_{2} \mathrm{~S}$, (16) $\mathrm{SO}_{3}{ }^{2-}$, (17) $\mathrm{NO}_{3}{ }^{-}$, (18) $\mathrm{CH}_{3} \mathrm{COO}^{-}$, (19) $\mathrm{SO}_{4}{ }^{2-}$, (20) $\mathrm{CO}_{3}{ }^{2-}$, (21) $\mathrm{PO}_{4}{ }^{3-}$, (22) $\mathrm{Na}^{+}$, (23) $\mathrm{K}^{+}$, (24) $\mathrm{Ca}^{2+}$, (25) $\mathrm{Mg}^{2+}$, (26) $\mathrm{Zn}^{2+},(27) \mathrm{Cu}^{2+},(28) \mathrm{Fe}^{2+}$, and (29) $\mathrm{Fe}^{3+}$. All tests were done in phosphate buffer (50 $\mathrm{mM}, \mathrm{pH}$ 7.4) with $4 \%$ DMSO after incubation at $37{ }^{\circ} \mathrm{C}$ for $5 \mathrm{~min}$. Fluorescence intensities at $418 \mathrm{~nm}$ (a) and $506 \mathrm{~nm}$ (b) were acquired with excitation at $340 \mathrm{~nm}$ and $380 \mathrm{~nm}$, respectively.

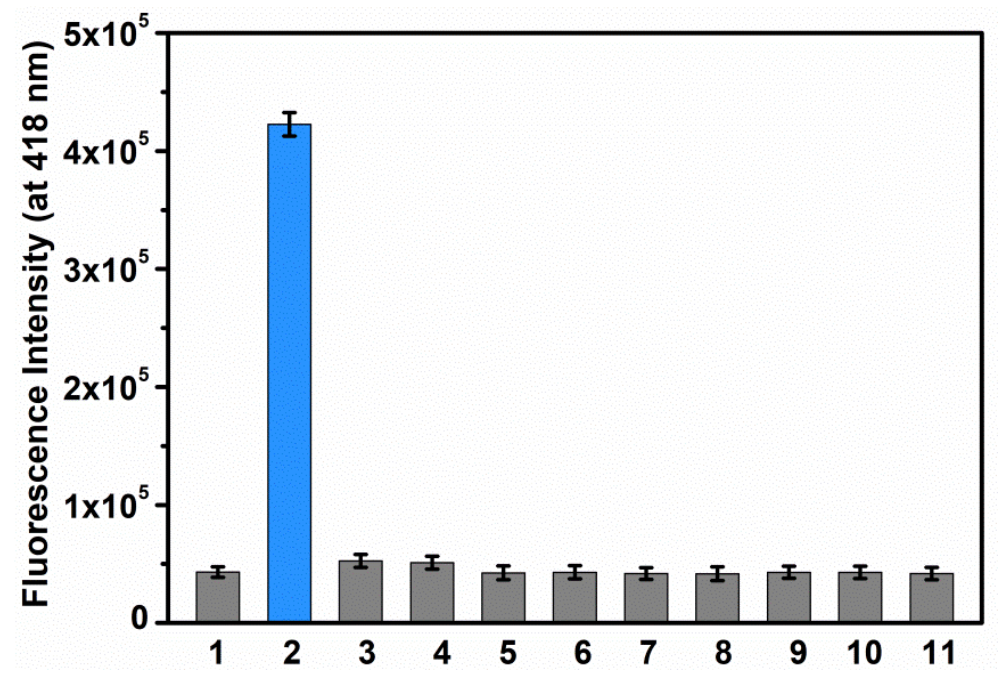

Figure S5. Fluorescence responses of $2 \mu \mathrm{M}$ BTNPO toward A $\beta$ aggregates $(20 \mu \mathrm{M})$ and other proteins or peptides (10 $\mu \mathrm{M})$ : (1) blank, (2) A $\beta$ aggregates, (3) HSA, (4) BSA, (5) hemoglobin, (6) $\beta$-lactoglobulin, (7) papain, (8) pepsin, (9) $\beta$-glucosidase, (10) AChE, and (11) $\beta$-lactamase. All tests were done in phosphate buffer (50 mM, $\mathrm{pH}$ 7.4) with $4 \%$ DMSO after incubation at $37^{\circ} \mathrm{C}$ for $30 \mathrm{~min}$. Fluorescence intensities at $418 \mathrm{~nm}$ were acquired with excitation at $340 \mathrm{~nm}$. 


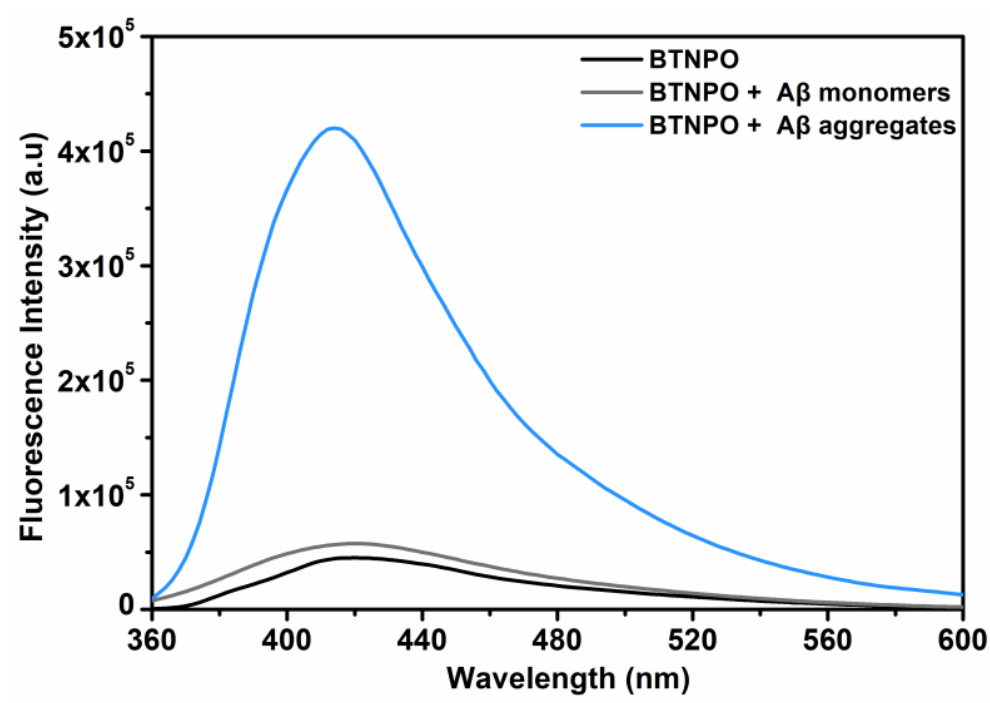

Figure S6. Fluorescence spectra of BTNPO alone (black line), BTNPO incubated with $\mathrm{A} \beta$ monomers (gray line) or $\mathrm{A} \beta$ aggregates (blue line). The final concentrations of BTNPO, A $\beta$ monomers, and $\mathrm{A} \beta$ aggregates were 2,20 , and $20 \mu \mathrm{M}$. The test was done in phosphate buffer (50 mM, pH 7.4) with 4\% DMSO after incubation at $37{ }^{\circ} \mathrm{C}$ for $5 \mathrm{~min}$. The blue emission was acquired with excitation at $340 \mathrm{~nm}$. 


\section{MTT assay}

PC12 cells were seeded into a 96 -well microtiter plate at $37{ }^{\circ} \mathrm{C}$ in a $5 \% \mathrm{CO}_{2} / 95 \%$ air incubator for $24 \mathrm{~h}$. The cells were incubated for an additional $12 \mathrm{~h}$ with different concentrations of tested probe $(0,1,10,20,50$, and $100 \mu \mathrm{M})$, respectively. Then the cells were washed with PBS three times. Subsequently, MTT solution (200 $\mu$ L, 0.5 $\mathrm{mg} / \mathrm{mL}$ ) was added to each well and the cells were incubated at $37^{\circ} \mathrm{C}$. After $4 \mathrm{~h}$, the remaining MTT was removed, and the formazan crystals were dissolved in $200 \mu \mathrm{L}$ of DMSO with gentle agitation for $5 \mathrm{~min}$. The absorbance at $490 \mathrm{~nm}$ was measured using a TRITURUS microplate reader.

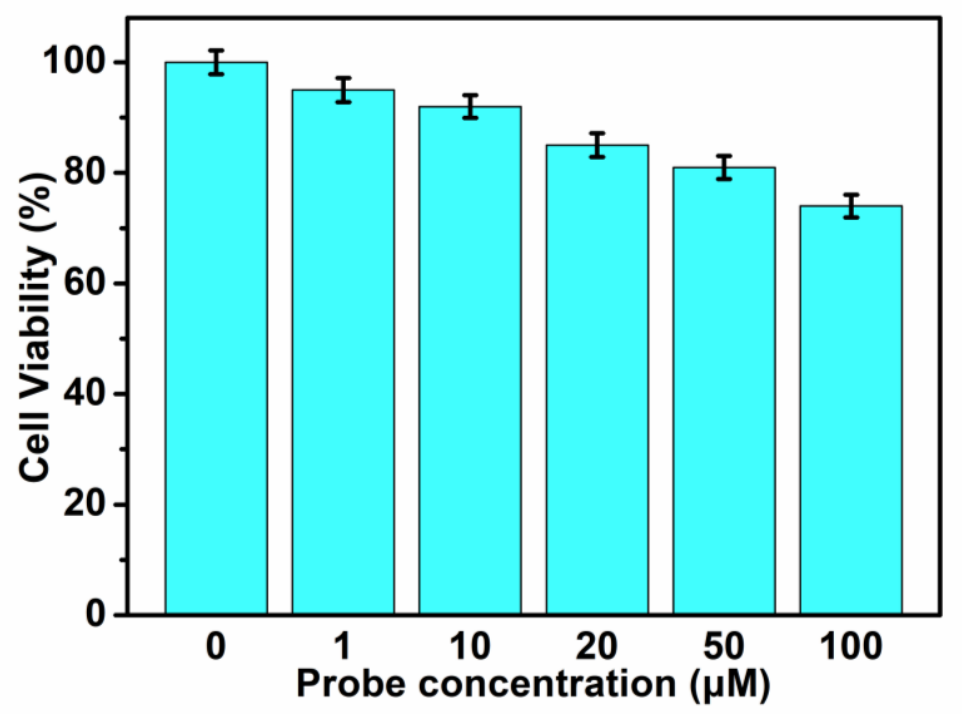

Figure S7. MTT assay of PC12 cells with different concentrations of BTNPO. The $\mathrm{IC}_{50}$ value was calculated to be $156.8 \mu \mathrm{M}$. 


\section{Cell culture and imaging}

PC12 and HepG2 cells were cultured in Dulbecco's Modified Eagle Medium (DMEM) supplemented with $10 \%$ fetal bovine serum, $1 \%$ penicillin, and $1 \%$ streptomycin at $37{ }^{\circ} \mathrm{C}$ in a $5 \% \mathrm{CO}_{2} / 95 \%$ air incubator (MCO-5AC, Sanyo). One day before imaging, the cells were detached and replanted on glass-bottomed dishes. Cell imaging was performed on a Zeiss LSM 880 confocal microscope, blue channel images (BTNPO) were obtained by collecting the emissions from 380 to $430 \mathrm{~nm}$ upon two-photon excitation at $700 \mathrm{~nm}$, green channel images (BTNPO) were obtained by collecting the emissions from 490 to $550 \mathrm{~nm}$ upon two-photon excitation at $750 \mathrm{~nm}$, and red channel images (Congo red) were obtained by collecting the emissions from 575 to $630 \mathrm{~nm}$ upon two-photon excitation at $800 \mathrm{~nm}$.

For monitoring of $\mathrm{ONOO}^{-}$released from SIN-1 in live cells, HepG2 cells were pretreated with $500 \mu \mathrm{M} \mathrm{SIN-1}$ for 30 min before being washed three times with PBS; then, they were incubated with $5 \mu \mathrm{M}$ BTNPO for 30 min before being rinsed with PBS. For the negative control group, the cells were pretreated with PBS instead of SIN-1. For the scavenging assay, the cells were treated with $100 \mu \mathrm{M}$ uric acid for $3 \mathrm{~h}$ in advance.

For monitoring of $\mathrm{ONOO}^{-}$variations induced by $\mathrm{A} \beta$ aggregates, $\mathrm{PC} 12$ cells were pretreated with $20 \mu \mathrm{M} \mathrm{A} \beta$ aggregates for $12 \mathrm{~h}$; then, they were incubated with $5 \mu \mathrm{M}$ BTNPO for 30 min before being rinsed with PBS. For the negative control group, the cells were pretreated with PBS instead of $A \beta$ aggregates. For the scavenging assay, the cells were treated with $100 \mu \mathrm{M}$ uric acid for $3 \mathrm{~h}$ in advance.

For monitoring of $\mathrm{ONOO}^{-}$variations induced by $\mathrm{A} \beta$ aggregates with different incubation time, PC12 cells were divided into six parallel groups and pretreated with $20 \mu \mathrm{M} A \beta$ aggregates for $0,3,6,9,12$, or $15 \mathrm{~h}$ respectively. Then they were incubated with $10 \mu \mathrm{M}$ BTNPO for 30 min before being rinsed with PBS.

For monitoring of $\mathrm{ONOO}^{-}$variations induced by $\mathrm{A} \beta$ aggregates with varied concentrations, PC12 cells were divided into six parallel groups and pretreated with 0 , 
$5,10,20,30$, or $40 \mu \mathrm{M} \mathrm{A} \beta$ aggregates for $12 \mathrm{~h}$ respectively. Then they were incubated with $10 \mu \mathrm{M}$ BTNPO for 30 min before being rinsed with PBS.

To explore the connection between $\mathrm{A} \beta$ stimulation and $\mathrm{ONOO}^{-}$production, $\mathrm{PC} 12$ cells were pretreated with $30 \mu \mathrm{M} A \beta$ aggregates for $12 \mathrm{~h}$; then, they were incubated with $10 \mu \mathrm{M}$ BTNPO for $30 \mathrm{~min}$ before being rinsed with PBS. For the negative control group, the cells were pretreated with PBS instead of A $\beta$ aggregates. For the inhibiting groups, the cells were pretreated with $1 \mu \mathrm{M}$ FPS-ZM1 and $30 \mu \mathrm{M} A \beta$ aggregates for $12 \mathrm{~h}$.

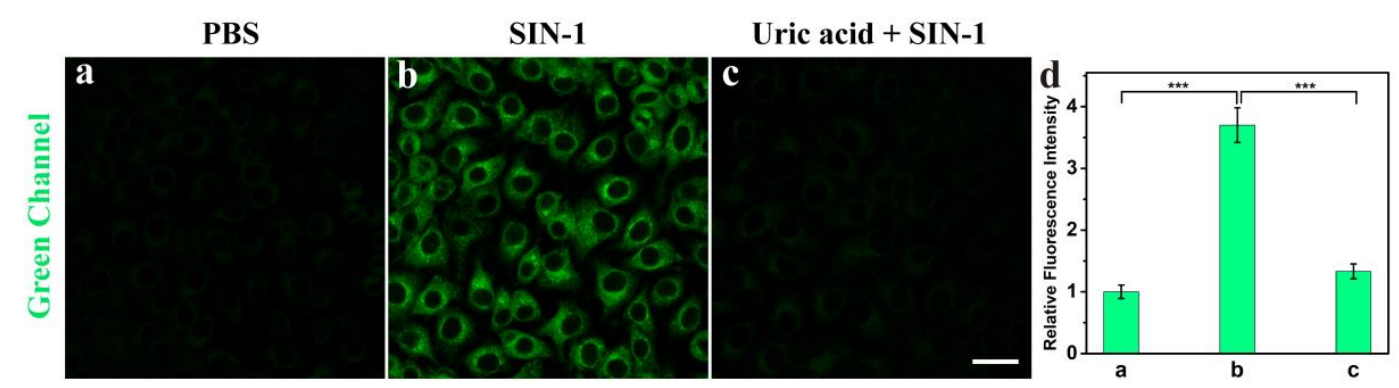

Figure S8. Two-photon fluorescence imaging of $\mathrm{ONOO}^{-}$in live cells. HepG2 cells were treated with (a) PBS, (b) SIN-1, and (c) uric acid with SIN-1, followed by incubation with $5 \mu \mathrm{M}$ BTNPO. (d) Relative fluorescence intensities of $(\mathrm{a}-\mathrm{c})$. The values are the mean $\pm \operatorname{sd}$ for $n=3, * * * p<0.001$. Green channel images were obtained by collecting the emissions from 490 to $550 \mathrm{~nm}$ upon two-photon excitation at $750 \mathrm{~nm}$. Scale bar represents $20 \mu \mathrm{m}$.
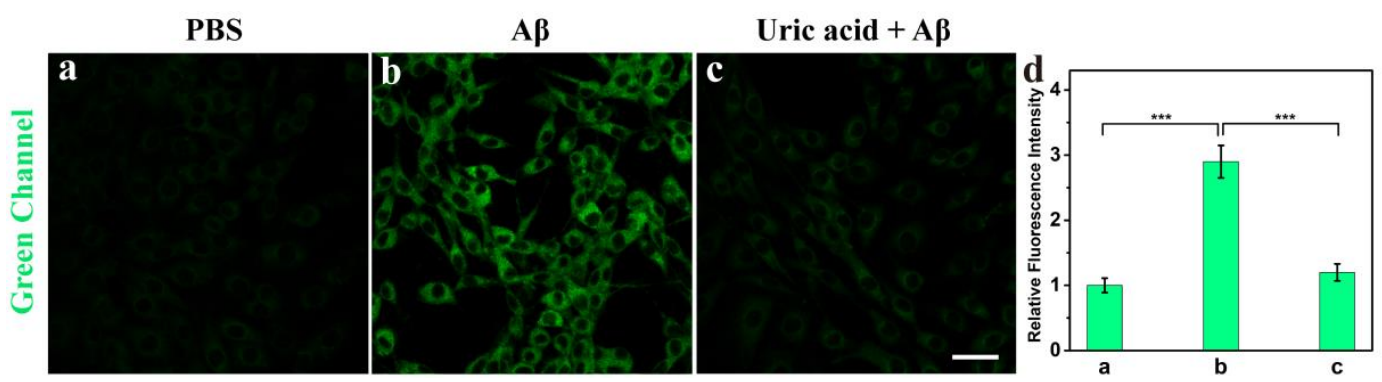

Figure S9. Two-photon fluorescence imaging of $\mathrm{ONOO}^{-}$induced by $\mathrm{A} \beta$ aggregates. PC12 cells were treated with (a) PBS, (b) A $\beta$ aggregates, and (c) uric acid with A $\beta$ aggregates, followed by incubation with $5 \mu \mathrm{M}$ BTNPO. (d) Relative fluorescence intensities of $(\mathrm{a}-\mathrm{c})$. The values are the mean \pm sd for $n=3$, *** $p<0.001$. Green channel images were obtained by collecting the emissions from 490 to $550 \mathrm{~nm}$ upon 
two-photon excitation at $750 \mathrm{~nm}$. Scale bar represents $20 \mu \mathrm{m}$.

\section{Western blotting}

For Western blots experiment, cells were incubated with $30 \mu \mathrm{M} A \beta$ aggregates for $12 \mathrm{~h}$ when they are grown to $80-85 \%$ confluence. As a comparison, another group of cells were incubated in PBS without $A \beta$ aggregates. Cells samples were collected by trypsinization and pelleted by centrifugation at $1000 \mathrm{rpm}$ for $3 \mathrm{~min}$ at $25^{\circ} \mathrm{C}$, followed by washing with PBS $(1 \mathrm{~mL})$ three times and the cell pellets were flash frozen in liquid nitrogen and ultrasonicated followed by centrifugation for $30 \mathrm{~min}$ with $20000 \mathrm{~g}$ at $4{ }^{\circ} \mathrm{C}$. The resulting supernatant (soluble cell lysate) was collected and protein concentration was determined via BCA assay (Pierce, Thermo Scientific). Protein concentration was adjusted to $2 \mathrm{mg} / \mathrm{mL}$ with PBS before use. Protein samples were mixed with the loading buffer, boiled for 5 min and set on ice immediately. Then samples and protein ladder were loaded onto the gel along with positive and negative controls. Gel was ran at $80 \mathrm{~V}$ for $20 \mathrm{~min}$ and followed by increasing to $120 \mathrm{~V}$ for a period of time depending on the position of the prey proteins on the gel. Next, proteins were transferred onto the membrane. Traditional sandwich method was used to transfer proteins from gel to membrane. Then, the membrane was sealed with QuickBlock ${ }^{\mathrm{TM}}$ Blocking Buffer for 15 min under room temperature, washed with the PBST buffer for three times, incubated with primary antibody (RAGE Antibody, 1 $\mu \mathrm{g} / \mathrm{ml}$ ) for $2 \mathrm{~h}$, washed with the PBST buffer for three times and incubated with a secondary antibody (Goat Anti-Rabbit $\operatorname{IgG}(\mathrm{H}+\mathrm{L}), 1:$ 8000) for $3 \mathrm{~h}$ at room temperature. After incubation, the samples were washed with the PBST buffer for three times and rinsed with PBS buffer. Finally, chemiluminescent detection of the bound bait protein was assayed by an ECL kit, according to the manufacturer's instruction. Blotting was imaged using a ChemiDoc ${ }^{\mathrm{TM}}$ Touch Imaging System (Bio-Rad). 


\section{Characterization of the nitrated $A \beta$ peptides}
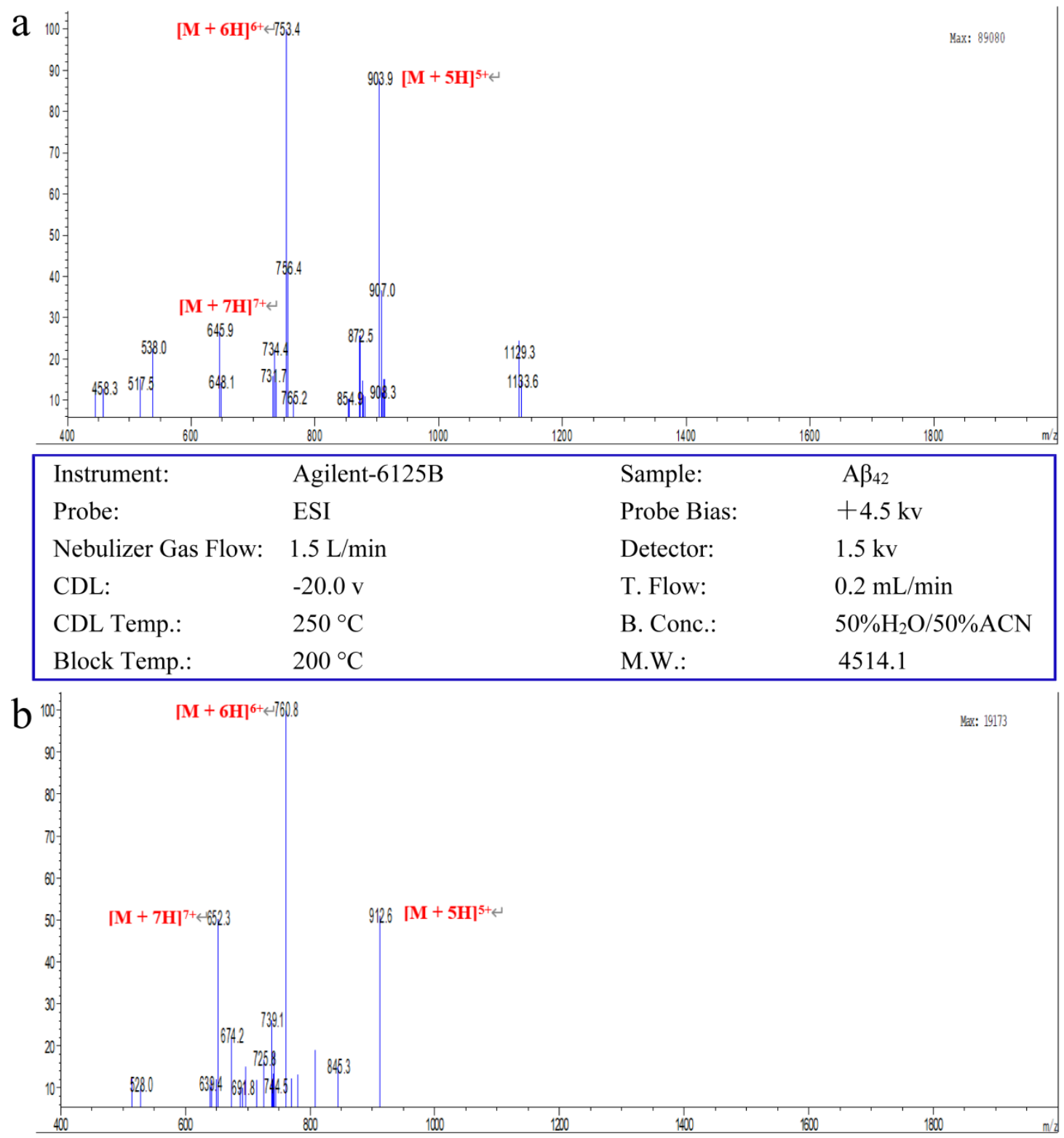

\begin{tabular}{|llll|}
\hline Instrument: & Agilent-6125B & Sample: & $\mathrm{A} \beta_{42}-\mathrm{NO}_{2}$ \\
Probe: & ESI & Probe Bias: & $+4.5 \mathrm{kv}$ \\
Nebulizer Gas Flow: & $1.5 \mathrm{~L} / \mathrm{min}$ & Detector: & $1.5 \mathrm{kv}$ \\
CDL: & $-20.0 \mathrm{v}$ & T. Flow: & $0.2 \mathrm{~mL} / \mathrm{min}$ \\
CDL Temp.: & $250^{\circ} \mathrm{C}$ & B. Conc.: & $50 \% \mathrm{H}_{2} \mathrm{O} / 50 \% \mathrm{ACN}$ \\
Block Temp.: & $200^{\circ} \mathrm{C}$ & M.W.: & 4559.03 \\
\hline
\end{tabular}

Figure S10. MS spectral analysis of tyrosine nitration of human $A \beta_{42}$ peptide induced by $\mathrm{ONOO}^{-}$. $\mathrm{ONOO}^{-}$was slowly added dropwise to $\mathrm{A} \beta_{42}$ solution (molar ratio = 1:1) with constant stirring and incubated at $37{ }^{\circ} \mathrm{C}$ for $1 \mathrm{~h}$. (a) $\mathrm{A} \beta_{42}$ peptide and (b) $\mathrm{A} \beta_{42}$ peptide treated with $\mathrm{ONOO}^{-}$were both analyzed by Coupling High Performance Liquid Chromatograph with Mass Spectrometer (Agilent-6125B). The molecular 
weight of human $A \beta_{42}$ peptide and its nitrated product was 4514.10 and 4559.03 respectively. The peaks emerged at $\mathrm{m} / \mathrm{z}$ 903.9, 753.4, and 645.9 in (a) were corresponding to $[\mathrm{M}+5 \mathrm{H}]^{5+},[\mathrm{M}+6 \mathrm{H}]^{6+}$, and $[\mathrm{M}+7 \mathrm{H}]^{7+}$ of $\mathrm{A} \beta_{42}$ peptide. The peaks emerged at m/z 912.6, 760.8, and 652.3 in (b) were corresponding to $[\mathrm{M}+5 \mathrm{H}]^{5+},[\mathrm{M}$ $+6 \mathrm{H}]^{6+}$, and $[\mathrm{M}+7 \mathrm{H}]^{7+}$ of the nitrated $\mathrm{A} \beta_{42}$ peptide.

\section{Mouse models}

All animal experiments were approved by the Animal Care and Use Committee of Shandong Normal University, and were performed in compliance with the Animal Management Rules of the Ministry of Health of the People's Republic of China and the Guidelines for the Care and Use of Laboratory Animals of Shandong Normal University.

The mice were fasted for $12 \mathrm{~h}$ to avoid possible food fluorescence interference to the dye fluorescence before imaging. The injection solution of BTNPO was freshly prepared in a mixture of 5\% DMSO and 95\% PBS. BTNPO $(20 \mathrm{mg} / \mathrm{kg})$ was injected intraperitoneally into healthy (6 months old) and APP/PS1 double transgenic mice (2-6 months old). Two hours later, after anesthesia, the mice were sacrificed, and the hippocampus region of the brain was isolated and sectioned into slices before two-photon fluorescence imaging. Blue channel images (for $\mathrm{A} \beta$ plaques) and green channel images (for $\mathrm{ONOO}^{-}$) in the brain hippocampus of healthy (6 months old) and AD mice (2-6 months old) were obtained. Next, the hippocampal tissues of 6-month-old AD mice were further incubated with $10 \mu \mathrm{M}$ Congo red for $30 \mathrm{~min}$, and A $\beta$ plaques were constained by BTNPO (blue channel) and Congo red (red channel). Subsequently, dual color two-photon images were obtained along the z-direction at depths of $20-120 \mu \mathrm{m}$ in the hippocampus of AD mice at 6 months old, and the three dimensional (3D) images were constructed from approximately 200 two-photon sections. Finally, the major organs (lungs, hearts, livers, and kidneys) of the 6-month-old wide-type mice and the age-matched $\mathrm{AD}$ mice were isolated and cut into slices for two-photon fluorescence imaging. After incubation with $500 \mu \mathrm{M} \mathrm{SIN-1}$ for 
30 min, the tissues of both the wide-type and AD mice were again imaged to examine the fluorescence variations compared with that without SIN-1 treatment. Blue channel images were obtained by collecting the emissions from 380 to $430 \mathrm{~nm}$ upon two-photon excitation at $700 \mathrm{~nm}$, green channel images were obtained by collecting the emissions from 490 to $550 \mathrm{~nm}$ upon two-photon excitation at $750 \mathrm{~nm}$, and red channel images were obtained by collecting the emissions from 575 to $630 \mathrm{~nm}$ upon two-photon excitation at $800 \mathrm{~nm}$. 

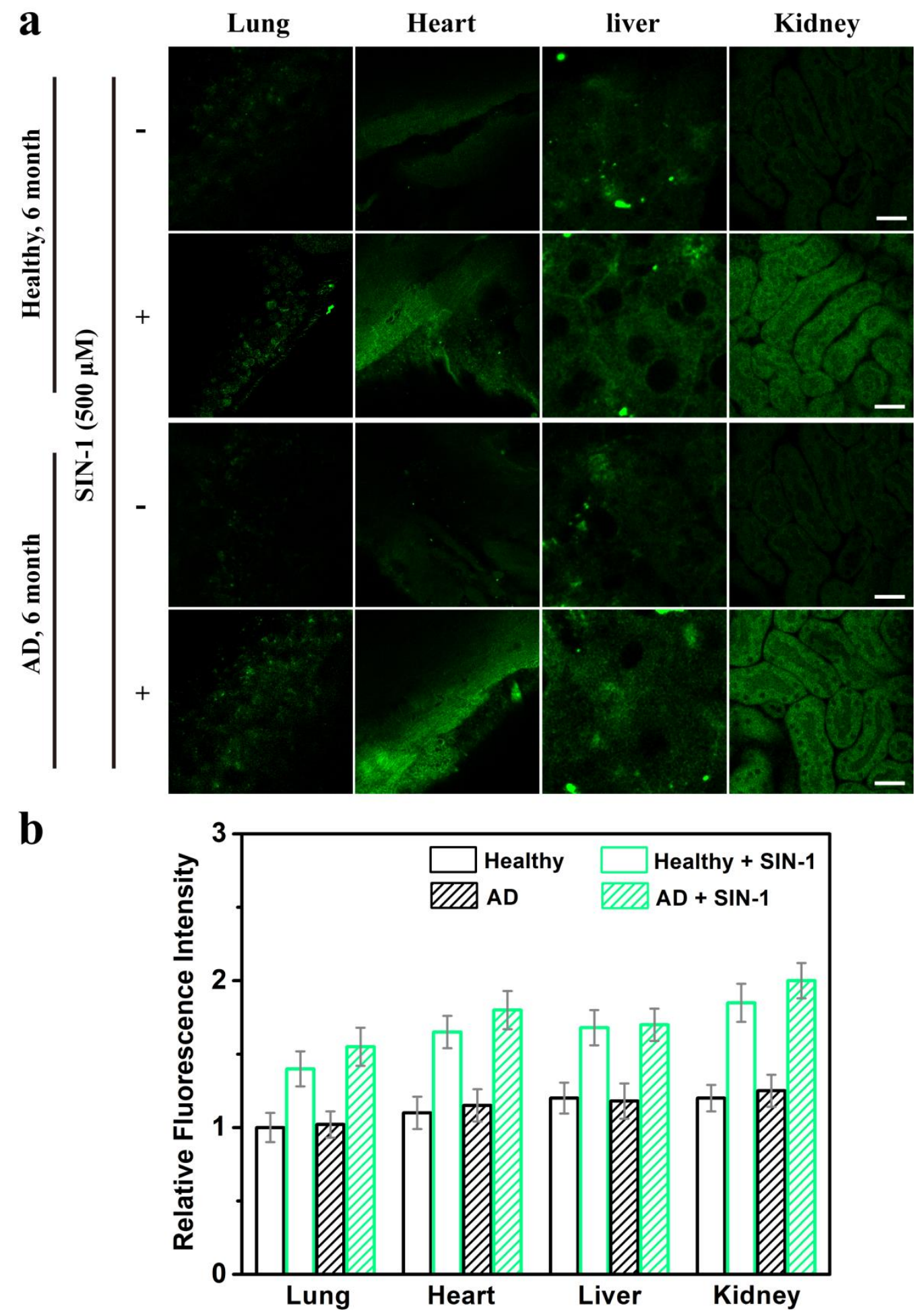

Figure S11. Two-photon fluorescence imaging of $\mathrm{ONOO}^{-}$in the major organs of the healthy and AD mice at 6 months old. (a) After BTNPO administration and anesthesia, the major organs (lungs, hearts, livers, and kidneys) of the healthy and AD mice at 6 months old in the experiment of Figure 4 were isolated and cut into slices for two-photon fluorescence imaging. After incubation with $500 \mu \mathrm{M} \mathrm{SIN}-1$ for $30 \mathrm{~min}$, 
the tissues of both the healthy and $\mathrm{AD}$ mice were again imaged to examine the fluorescence variations in the green channel compared with that without SIN-1 treatment. The green channel images were obtained by collecting the emissions from 490 to $550 \mathrm{~nm}$ upon two-photon excitation at $750 \mathrm{~nm}$. Scale bar represents $40 \mu \mathrm{m}$. (b) Relative mean fluorescence intensities in the green channel were quantified.

\section{NMR and HRMS spectra}

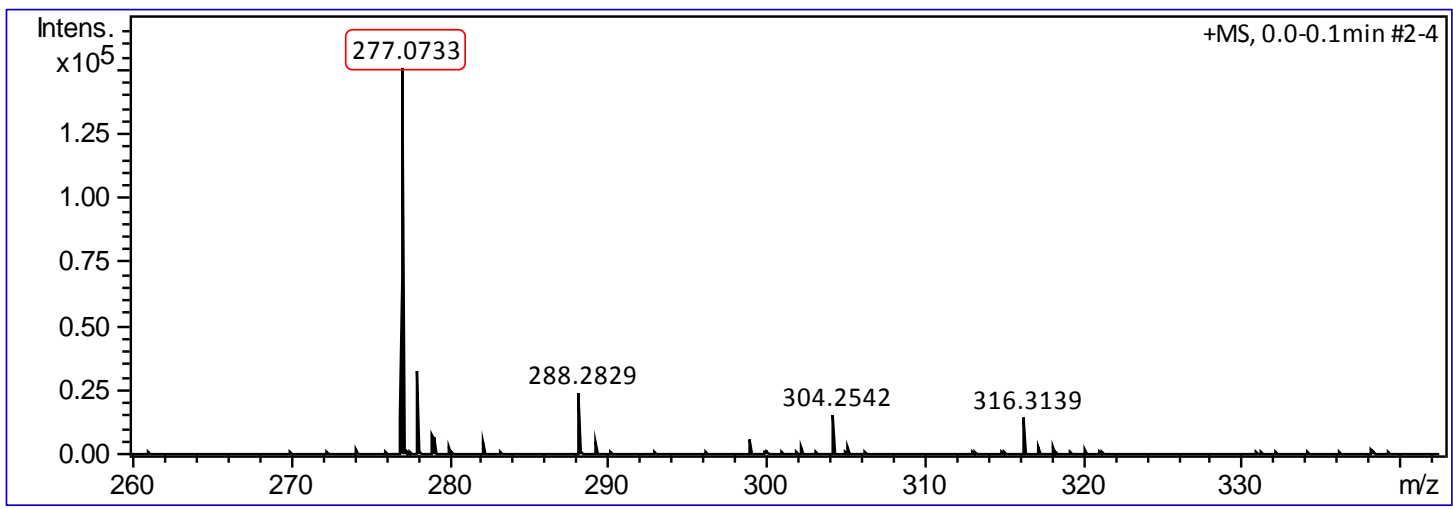

Figure S12. HRMS spectrum of Compound 1

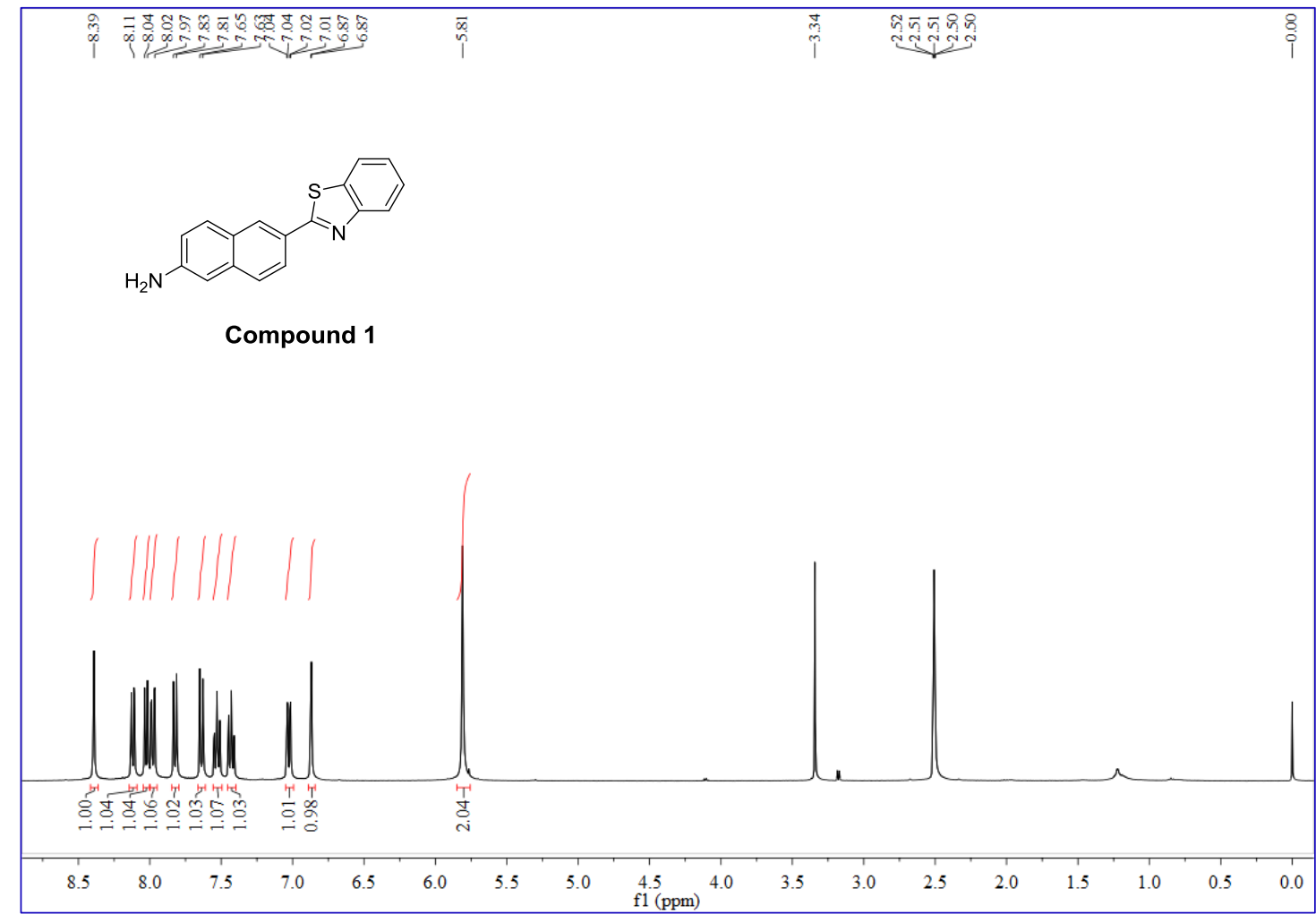

Figure 13. ${ }^{1} \mathrm{H}$ NMR spectrum of Compound 1 


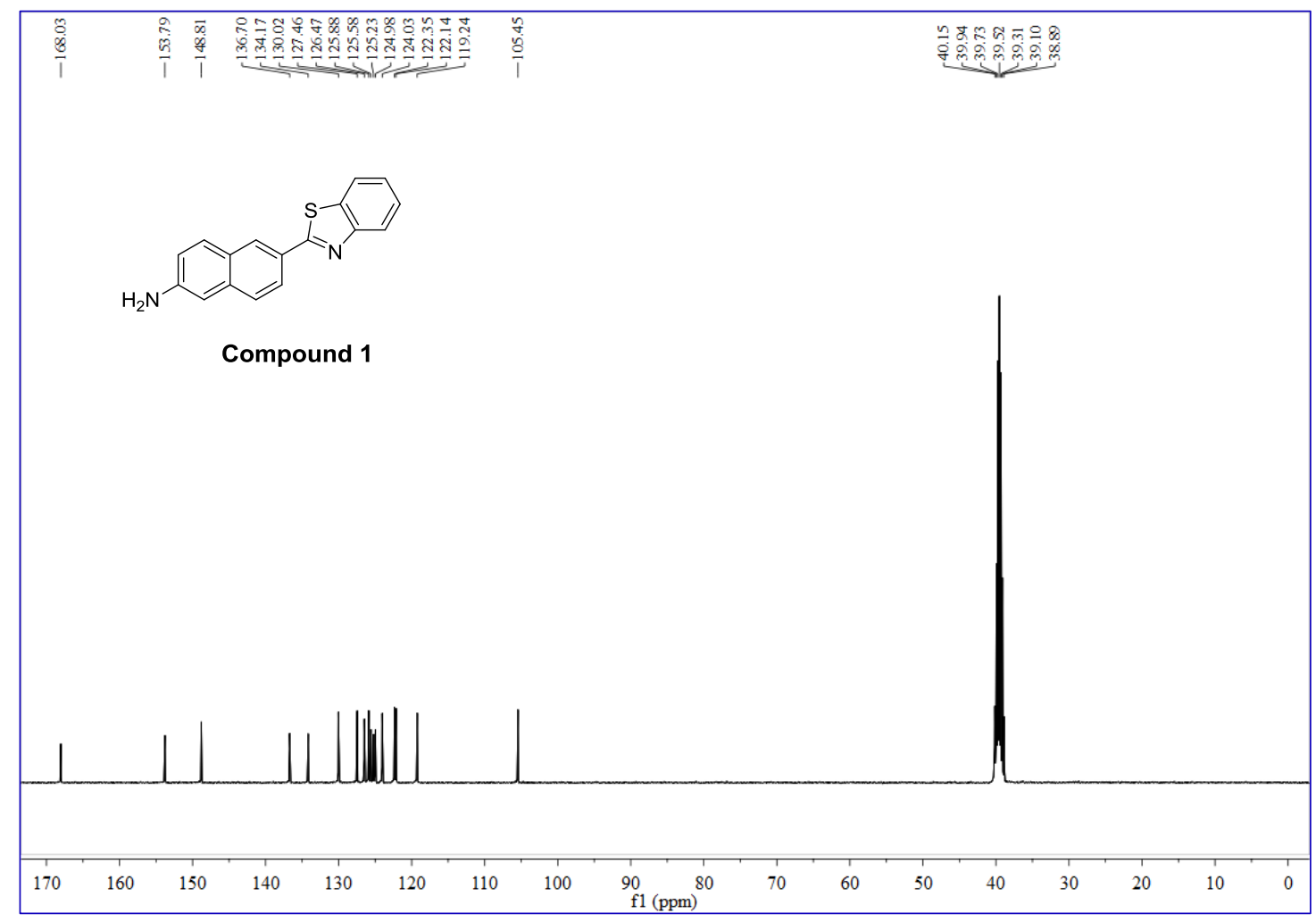

Figure S14. ${ }^{13} \mathrm{C}$ NMR spectrum of Compound 1

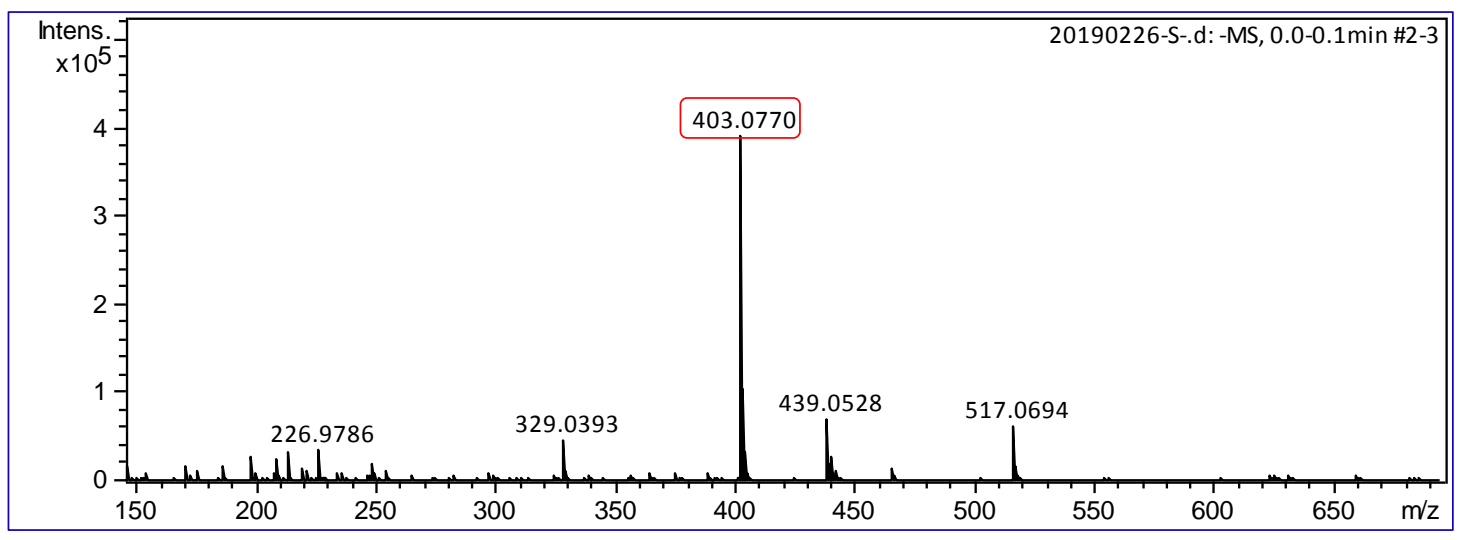

Figure S15. HRMS spectrum of BTNPO 


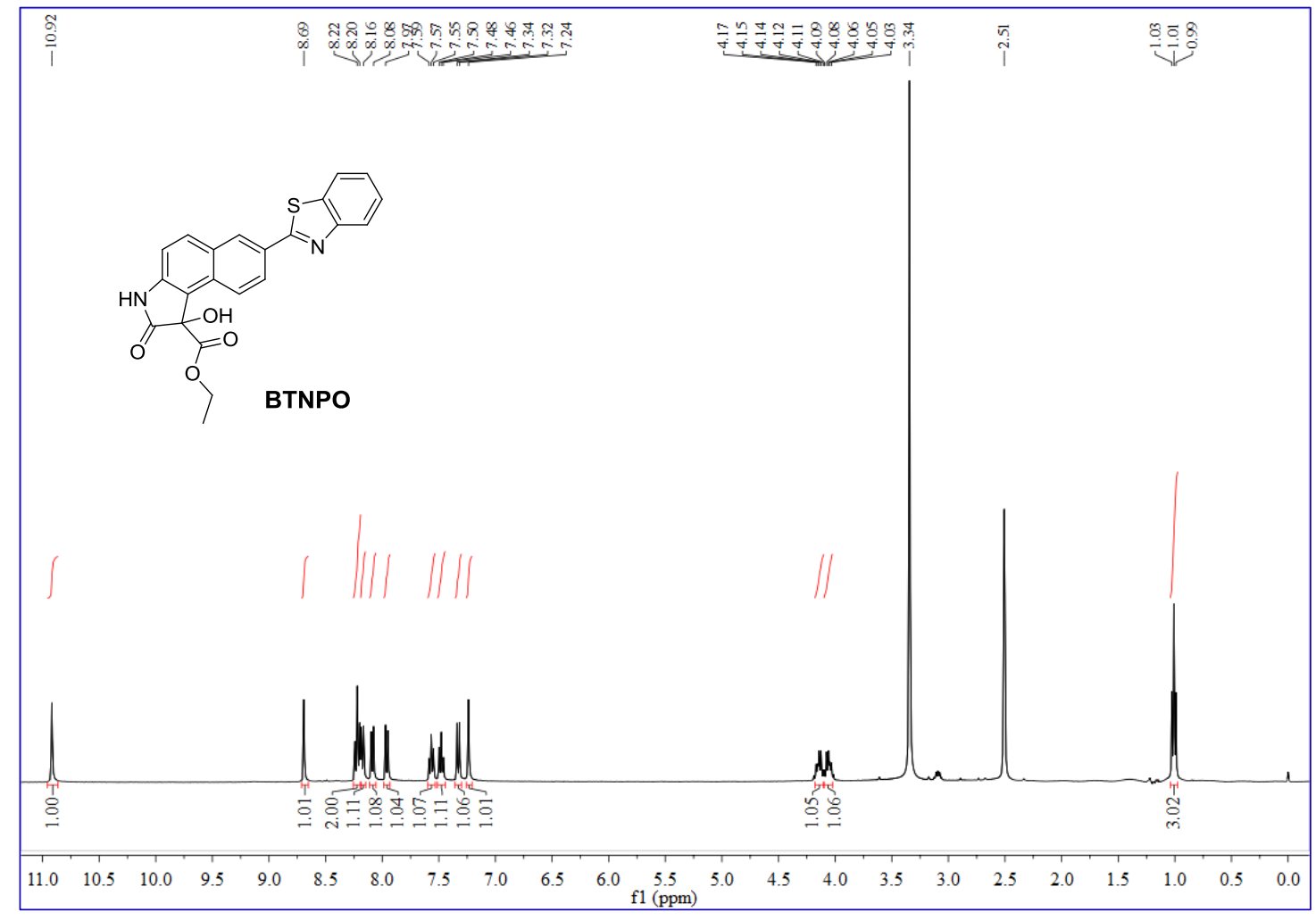

Figure S16. ${ }^{1} \mathrm{H}$ NMR spectrum of BTNPO

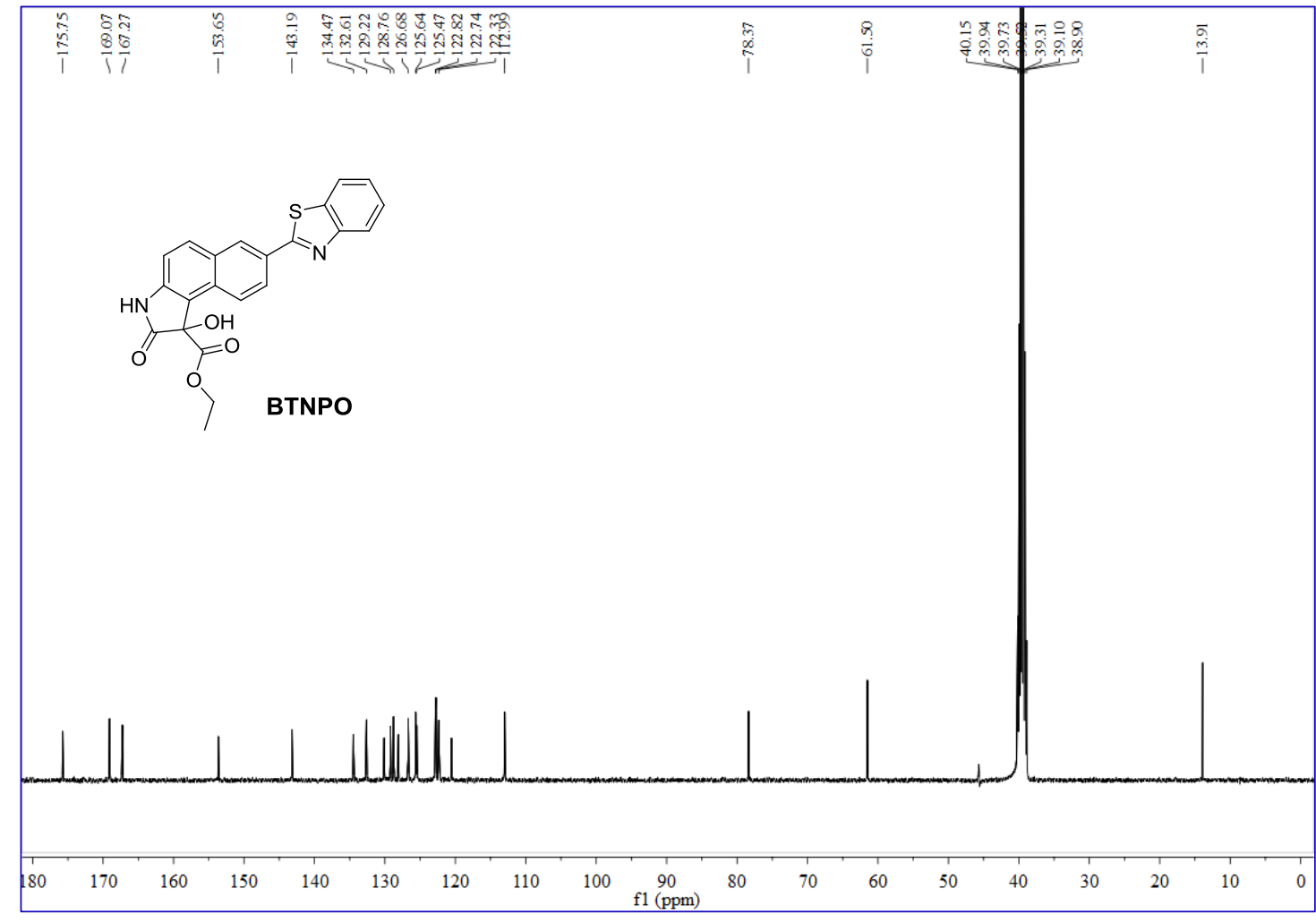

Figure S17. ${ }^{13} \mathrm{C}$ NMR spectrum of BTNPO 